\title{
Hair Tonic Formulation of Black Tea Extract (Camellia sinensis) as Hair Growth
}

\section{Nurul Arfiyanti Yusuf*; Besse Hardianti; Rahma}

Departement of Pharmacy, Sekolah Tinggi Ilmu Farmasi Makassar, Jl. Perintis Kemerdekaan, Pai, Kec. Biringkanaya, Kota Makassar, Sulawesi Selatan 90242

\section{Abstract}

Black tea contains flavonoid and its derivate which is a mechanism of actions to stimulate and increase cell proliferation of hair dermal papilla cell to suppress the production of tumor necrosis factor alpha (TNF alpha) that trigger baldness. This study aimed to determine the stable hair tonic formula and to investigate the effectiveness of black tea extract hair tonic in rabbits (oryctolagus cuniculus) as animal testing. There were 3 different concentrations used in this study namely formula 1 ( $1.25 \%$ of black tea extract), formula 2 ( 2.5 $\%$ of black tea extract) and formula 3 (5\% of black tea extract). The physical stability evaluation was conducted using some tests such as organoleptic, $\mathrm{pH}$, density determination and viscosity test. The

\section{Data of article}

Received : 31 July 2021

Reviewed: og Aug 2021

Accepted : 25 Aug 2021

\section{DOI}

10.18196/jfaps.v2i1.12451

\section{Type of article:}

Research result of this evaluation showed that all the three formulas were stable, its effectiveness as hair restorer then was tested and the result of this test indicated that black tea extract has activity as a hair fertilizer and the optimum extract was shown by the formula 3 with black tea extract concentration of $5 \%$ with the hair growth in the $18^{\text {th }}$ day i.e., $9.62 \pm 0.365 \mathrm{~mm}$.

Keywords: black tea; hair tonic; hair growth

\section{INTRODUCTION}

Hair is a horn that is obliquely embedded in the hair follicle. Hair is known as a crown for women. Having beautiful and healthy hair will make a woman look beautiful. Hair beauty and health can be obtained from hair cleanliness; therefore, the scalp and hair need care to remain clean and healthy. Problems that arise due to not taking care of the scalp and hair include hair loss. ${ }^{1}$

Hair loss is a disorder in which the hair is shed less or more than normal, with or without visible thinning. The normal number of hair follicles on the head is around 100.000 , and it is called abnormal if the number only reaches $50 \%$, which means 50.000 strands. Normally, 80-120 strands of hair are shed per day ${ }^{2}$. Hair loss occurs in many people to reduce its function and protection against the body and head environment. It is not lifethreatening but affects self-confidence and can even be a psychological stressor. ${ }^{3}$ Haircare is not enough to use shampoo and conditioner because hair is a living cell, so it needs to be cared for and given fertilizer to grow healthy and beautiful. One way to do this is to use a hair grower, commonly known as a hair tonic. ${ }^{4}$

Hair tonic is a preparation of hair cosmetics used to thicken or stimulate hair growth in baldness or hair loss. Hair tonic

\footnotetext{
*Corresponding author, e-mail: ikhlasiyahyusufnurul@gmail.com
} 
contains solvents, active substances, and vasodilators that enlarge blood vessels to trigger hair growth, including pilocarpine and minoxidil, sebum gland stimulants, hair conditioner substances, and perfumes. The benefits of cosmetic hair tonic include increasing hair growth, preventing hair loss, eliminating dandruff, and being a source of hair nutrition. ${ }^{5,6}$

In this case, black tea (Camellia sinensis) is one of the plants that are useful for fertilizing hair. The active compounds in black tea are polyphenols, theophylline, flavonoids, tannins, caffeine, vitamins $C$ and $\mathrm{E}$, and several minerals, such as $\mathrm{Zn}$, Se, $\mathrm{Mo}, \mathrm{Ge}, \mathrm{Mg}$, which are beneficial for hair care ${ }^{7}$. Black tea leaf catechin has major components: epicatechin (EC), epicatechin gallate (ECG), epigallocatechin gallate (EGCG), gallocatechin gallate (GCG), gallocatechin $(G C)$, catechin gallate (CG), catechin (C), theaflavins, and thearubigins. Epigallocatechin gallate influences hair follicles and dermal papilla cells, indicating that hair follicle cultures have increased hair elongation and growth; dermal papilla cells also have more substantial proliferation than controls. ${ }^{8}$ For this reason, this study aims to obtain data on the hair tonic formula of black tea extract, which is effective for hair growth.

\section{METHOD}

The materials used in this study included distilled water, 70\% ethanol, propylene glycol, menthol, sodium metabisulfite, sodium benzoate, minoxidil, and black tea (Camellia sinensis). Samples of black tea leaves processed in the form of black tea products were obtained from a tea processing factory located in Malino, Gowa Regency (PT. Malino Highlands).

\section{Preparation of Experimental Animals}

Before testing the effectiveness of hair growth in rabbits, rabbits had to be adapted for seven days. The rabbits consisted of four rabbits; one experimental animal on the back was divided into six boxes, three left and three right sections with an area of $2 \times 2 \mathrm{~cm}^{2}$ each with a considerable distance of $2 \mathrm{~cm}^{2}$, while three experimental animals were divided into two boxes, one left and one right with $2 \times 2$ each. The hair in each box was shaved until bald and then smeared with ethanol to prevent irritation. ${ }^{9}$

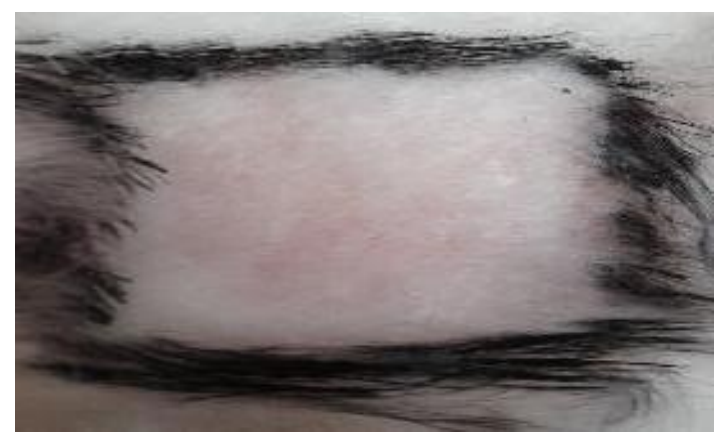

Figure 1. The back of the treated rabbit

\section{Making Black Tea Extract}

The extracts were made by maceration with a ratio of 1:7.5. Simplicia powder of 300 grams was put in a container containing $2.250 \mathrm{ml}$ of $70 \%$ ethanol. The container was tightly closed and protected from sunlight for three days while stirring regularly every day. After three days, the maceration was filtered through filter paper. Remaceration was carried out twice. The filtrate was then accommodated in a beaker glass and then concentrated with a rotary evaporator until the solvent was wholly lost and a thick extract was obtained. ${ }^{10}$

\section{Making Formula of Black Tea Extract Hair Tonic}

The black tea extract was weighed, then the extract was dissolved in distilled water until completely dissolved. Then, propylene glycol was added and stirred 
until homogeneous. Sodium metabisulfite and sodium benzoate were dissolved in distilled water respectively until dissolved; then, the black tea extract solution, which had been dissolved in propylene glycol, was added and stirred until homogeneous. After that, the menthol was dissolved in ethanol until dissolved, and the black tea extract solution, sodium metabisulfite solution, and sodium benzoate solution were added little by little and stirred until homogeneous.

Table 1. Formula Design for Hair Tonic of Black Tea Extract

\begin{tabular}{|c|c|c|c|c|c|c|}
\hline \multirow[b]{2}{*}{ Ingredients } & \multirow[b]{2}{*}{ Function } & \multicolumn{5}{|c|}{ Concentration (\%) } \\
\hline & & $\begin{array}{c}\text { Negative } \\
\text { Control }\end{array}$ & $\begin{array}{l}\text { Positive } \\
\text { Control }\end{array}$ & $\mathrm{F}_{1}$ & $F_{2}$ & $F_{3}$ \\
\hline $\begin{array}{l}\text { Black tea } \\
\text { ethanol extract }\end{array}$ & $\begin{array}{l}\text { Active } \\
\text { ingredient }\end{array}$ & - & - & 1.25 & 2.5 & 5 \\
\hline Minoxidil & Vasodilator & - & 2 & - & - & - \\
\hline Ethanol $70 \%$ & Solvent & 60 & 60 & 60 & 60 & 60 \\
\hline $\begin{array}{l}\text { Propylene } \\
\text { glycol }\end{array}$ & Enhancer & 10 & 1 & 10 & 10 & 10 \\
\hline $\begin{array}{l}\text { Sodium } \\
\text { benzoate }\end{array}$ & Preservative & 0.25 & 0.25 & 0.25 & 0.25 & 0.25 \\
\hline Menthol & $\begin{array}{l}\text { Cooling } \\
\text { Sensation }\end{array}$ & 0.1 & 0.1 & 0.1 & 0.1 & 0.1 \\
\hline $\begin{array}{l}\text { Sodium } \\
\text { metabisulfite }\end{array}$ & Antioxidant & 0.2 & 0.2 & 0.2 & 0.2 & 0.2 \\
\hline Distilled water & Solvent & $\operatorname{Ad} 100$ & $\operatorname{Ad} 100$ & Ad 100 & Ad 100 & Ad 100 \\
\hline $\begin{array}{l}\text { Information: } \\
F_{1}=\text { Hair tonic prepar } \\
F_{2}=\text { Hair tonic prepar } \\
F_{3}=\text { Hair tonic prepar }\end{array}$ & $\begin{array}{l}\text { on with } 1.25 \% \text { b } \\
\text { on with } 2.5 \% \mathrm{~b} \\
\text { on with } 5 \% \mathrm{blac}\end{array}$ & $\begin{array}{l}\text { tea extract } \\
\text { ea extract } \\
\text { extract }\end{array}$ & & & & \\
\hline
\end{tabular}

\section{Evaluation of Black Tea Extract Hair Tonic Formula}

\section{Accelerated Storage Test}

One way to speed up stability evaluation is to conduct tests before and after storage for several periods at higher and normal temperatures. This test can be carried out using a climatic chamber, consisting of one cycle with a temperature of $5^{\circ} \mathrm{C}$ for 12 hours and $35^{\circ} \mathrm{C}$ for 12 hours. In this study, the test was carried out for ten cycles. ${ }^{11}$

\section{Organoleptic Test}

The organoleptic test on the preparation was observed visually, including the preparation's color, smell, and shape before and after the accelerated storage test.

\section{pH Test}

The $\mathrm{pH}$ test was carried out using a $\mathrm{pH}$ meter; the electrode on the $\mathrm{pH}$ meter was calibrated with standard buffers of $\mathrm{pH} 4$ and $\mathrm{pH}$ 7. Then, the electrode was dipped into the preparation being examined and then waited for a stable value to appear and recorded the $\mathrm{pH}$ value that appeared on the screen. The $\mathrm{pH}$ of the hair tonic preparation was adjusted to the head $\mathrm{pH}$, which is in the $\mathrm{pH}$ range of $4 \cdot 5-6 \cdot 5 \cdot 4,5$

\section{Density Test}

Density was measured using a clean and dry pycnometer. At room temperature, 
the pycnometer (w1) was weighed and then filled with distilled water; the outside of the pycnometer was wiped dry and weighed (w2). The distilled water was discarded. The pycnometer was dried and then filled with hair tonic preparations, whose density was measured and then weighed $\left(\mathrm{W}_{3}\right) \cdot{ }^{12}$

\section{Viscosity Test}

Viscometer measurements of hair tonic preparations were carried out using an Ostwald viscometer. The hair tonic preparation was pipetted into the Ostwald viscometer utilizing a pipette, and then the liquid was sucked in using a bull pump until it crossed two limits. The time for the liquid for the first limit was measured using a stopwatch, and the results were recorded. The samples measured before and after the accelerated storage test was carried out and then calculated using the following formula. ${ }^{12}$

\section{Effectiveness Test for Black Tea Extract Hair Tonic}

Giving hair tonic was done twice a day, as much as $1 \mathrm{ml}$. The first day of giving was considered day zero. Observations were made for 18 days, and the effectiveness tests were carried out on the 6th, 12th, and 18th days. Group 1 was not smeared with preparations as normal control. Group 2 was smeared with a base as a negative control. Group 3 was smeared with formula 1, with an extract concentration of $1.25 \%$. Group 4 was smeared with formula 2, namely preparations with an extract concentration of $2.5 \%$. Group 5 was smeared with formula 3, namely preparations with an extract concentration of $5 \%$. Group 6 was smeared with minoxidil as a positive control. ${ }^{13}$

In addition, observations were made by taking six strands of rabbit hair by pulling them out using straightened tweezers.
They were placed on a dark base, pasted with tape, and then the longest rabbit hair was measured utilizing a caliper. The average hair length data obtained were statistically processed to see the difference between the test and control areas.

\section{Data Analysis}

The effectiveness test of hair fertilizer included the rate of hair growth. The rate of hair growth was obtained from the length of the hair. The hair length data obtained were then statistically processed using One Way ANOVA.

\section{RESULTS AND DISCUSSION}

The plant used in this research was Camellia sinensis or better known as black tea. The black tea used came from tea plantations in Malino, Gowa Regency. Black tea is the result of plants processed that are empirically widely used to nourish hair. In this study, black tea was made in hair tonic preparations to test its effectiveness in hair growth.

In this research, propylene glycol was used as a penetration enhancer in the skin. Menthol was meant to provide a cooling sensation to the skin. Sodium metabisulfite was used as an antioxidant to prevent oxidation in black tea extracts. Meanwhile, sodium benzoate was used as a preservative because its water content could be used as a medium for microbial growth.

Then, in this study, formulations with different extract concentrations but the same carrier were made to find the best formulation to increase optimal hair growth and hair density. 


\section{Physical Stability Test}

\section{Organoleptic Test Results}

Table 2. Organoleptic Test Results of Black Tea Extract

\begin{tabular}{|c|c|c|c|c|c|c|}
\hline \multirow[t]{2}{*}{$\begin{array}{l}\text { Hair Tonic } \\
\text { Formulation }\end{array}$} & $\begin{array}{l}\text { Before } \\
\text { condition }\end{array}$ & accelerate & storage & $\begin{array}{l}\text { After } \\
\text { condition }\end{array}$ & accelerated & storage \\
\hline & Color & Smell & Shape & Color & Smell & Shape \\
\hline $\mathrm{F}_{1}$ & Brown & $\begin{array}{l}\text { Typical } \\
\text { tea }\end{array}$ & Liquid & Brown & Typical tea & Liquid \\
\hline $\mathrm{F}_{2}$ & Brown & $\begin{array}{l}\text { Typical } \\
\text { tea }\end{array}$ & Liquid & Brown & Typical tea & Liquid \\
\hline$F_{3}$ & $\begin{array}{l}\text { Almost } \\
\text { black, } \\
\text { brown }\end{array}$ & $\begin{array}{l}\text { Typical } \\
\text { tea }\end{array}$ & Liquid & $\begin{array}{l}\text { Almost } \\
\text { black, } \\
\text { brown }\end{array}$ & Typical tea & Liquid \\
\hline
\end{tabular}

The organoleptic test of hair tonic preparations was carried out to determine each formula's color, smell, and shape. Organoleptic observations of the three hair tonic formulas showed that the greater the concentration of black tea extract used in the preparation, the preparation became almost blackish browner. Preparations subjected to accelerated storage conditions did not change in color, smell, and shape. If there is a change in the color of the hair tonic after testing, it is possible that a chemical reaction will occur, which will determine the hair tonic.

pH Test Results

Table 3. pH Test Results of Hair Tonic Black Tea Extract

\begin{tabular}{lll}
\hline $\begin{array}{l}\text { Hair Tonic } \\
\text { Formulation }\end{array}$ & $\begin{array}{l}\text { Before accelerated storage } \\
\text { conditions }\end{array}$ & $\begin{array}{l}\text { After accelerated storage } \\
\text { conditions }\end{array}$ \\
\cline { 2 - 3 } & $\mathrm{pH}$ & $\mathrm{pH}$ \\
$\mathrm{F}_{1}$ & 6.5 & 6.0 \\
$\mathrm{~F}_{2}$ & 6.1 & 5.9 \\
$\mathrm{~F}_{3}$ & 5.9 & 5.7 \\
\hline
\end{tabular}

In the observation data, the addition of black tea extract influenced the $\mathrm{pH}$ value of the preparation, where the higher the concentration of the added extract, the lower the $\mathrm{pH}$ value tended to be. The $\mathrm{pH}$ measurement results before and after accelerated storage conditions revealed that the three formulas experienced a decrease in $\mathrm{pH}$ values but still had $\mathrm{pH}$ values that met the $\mathrm{pH}$ range for the scalp $(4.5-6.5)$ so that the hair tonic preparations could be said to be stable. 4,5 


\section{Density Test Results}

Table 4. Density Results of Hair Tonic Black Tea Extract

\section{Hair Tonic Formulation}

$\mathrm{F}_{1}$

$\mathrm{F} 2$

$\mathrm{F}_{3}$
Before accelerated storage conditions

Density (g/ml)

0.9565

0.9474

0.9366
After accelerated storage conditions Density ( $\mathrm{g} / \mathrm{ml})$

0.9188

0.9230

0.9330
In this study, the density measurement of hair tonic preparations used a pycnometer. Measurements were carried out before and after being given accelerated storage conditions. The test results showed that the density of each formula was less than 1 . The three formulas showed different results, where the higher the extract concentration, the lower the density of the hair tonic preparation. Related to this, the density of a substance should remain stable in storage until used to be stable.

\section{Viscosity Test Results}

Table 5. Viscosity Results of Hair Tonic Black Tea Extract

\begin{tabular}{lll}
\hline $\begin{array}{l}\text { Hair Tonic } \\
\text { Formulation }\end{array}$ & $\begin{array}{l}\text { Before accelerated storage } \\
\text { conditions }\end{array}$ & $\begin{array}{l}\text { After accelerated storage } \\
\text { conditions }\end{array}$ \\
\hline$F_{1}$ & 0.0057 Poise & 0.0054 Poise \\
$F_{2}$ & 0.0054 Poise & 0.0052 Poise \\
$F_{3}$ & 0.0053 Poise & 0.0054 Poise \\
\hline
\end{tabular}

Viscosity testing was performed utilizing an Ostwald viscometer on preparations before and after being given accelerated storage conditions. Viscosity affects the density value-the greater the value of viscosity, the greater the density of the preparation. Viscosity is a measure of physical properties that are usually measured to estimate the effect of pressure conditions on the preparation and can be used as a parameter to indicate the stability of cosmetic products during storage.

Viscosity is a statement of the resistance of a liquid to flow; the higher the viscosity, the higher the resistance ${ }^{4,5}$. From the test data, the differences in the viscosity values of each formula were obtained; the higher the amount of extract added, the lower the viscosity value of the preparation.

Based on the statistical value for the viscosity test, it was found that the viscosity values before and after the accelerated storage condition were not significant $(p<0.05)$. It signifies that the hair tonic formula was stable under conditions before and after the accelerated storage conditions.

\section{Effectiveness Test of Hair Tonic Preparations}

The hair growth effectiveness test of the formula of black tea extract hair tonic was on male rabbit hair. The rabbits used consisted of four male rabbits. Observations were made for 18 days, and the effectiveness test was carried out on the 6th, 12th, and 18th days. From the 
data obtained from hair length measurement, the average rabbit hair length was calculated for each treatment. The calculation results of the average hair extension per treatment per six days can be seen in Table 6.

Table 6. The effectiveness test results of preparations of black tea extract hair tonic

\begin{tabular}{lllll}
\hline No. & Group & \multicolumn{2}{l}{ Hair length $(\mathbf{m m})$} & \\
& & $6^{\text {th }}$ day & $\mathbf{1 2}^{\text {th }}$ day & $\mathbf{1 8}^{\text {th }}$ day \\
\hline 1 & Normal Control & $1.64 \pm 0.131$ & $3.81 \pm 0.275$ & $6.60 \pm 0.355$ \\
2 & Negative Control & $1.66 \pm 0.134$ & $3.82 \pm 0.307$ & $6.43 \pm 0.305$ \\
3 & F1 & $1.65 \pm 0.088$ & $5.11 \pm 0.375$ & $7.87 \pm 0.386$ \\
4 & F2 & $1.75 \pm 0.126$ & $5.80 \pm 0.305$ & $8.94 \pm 0.417$ \\
5 & F3 & $1.69 \pm 0.126$ & $6.13 \pm 0.234$ & $9.62 \pm 0.365$ \\
6 & Positive Control & $1.78 \pm 0.13$ & $6.62 \pm 0.221$ & $10.54 \pm 0.363$ \\
\hline
\end{tabular}

Based on the results of the average hair length measurement, it is known that the lowest rabbit hair growth was in the negative control group and then the untreated group, followed sequentially by formula $1(1.25 \%)$, formula $2(2.5 \%)$, and formula $3(5 \%)$. Meanwhile, the highest hair growth was in the positive control group (minoxidil).

\begin{tabular}{|c|c|c|c|}
\hline Group & $6^{\text {th }}$ day & $12^{\text {th }}$ day & $18^{\text {th }}$ day \\
\hline Untreated & & & \\
\hline Negative Control & & & \\
\hline $\mathrm{F}_{1}$ & & & \\
\hline $\mathrm{F}_{2}$ & & & \\
\hline$F_{3}$ & & & \\
\hline Positive Control & & & \\
\hline
\end{tabular}

Figure 2. Test Area of Black Tea Extract Hair Tonic Preparations on Rabbit's Back 


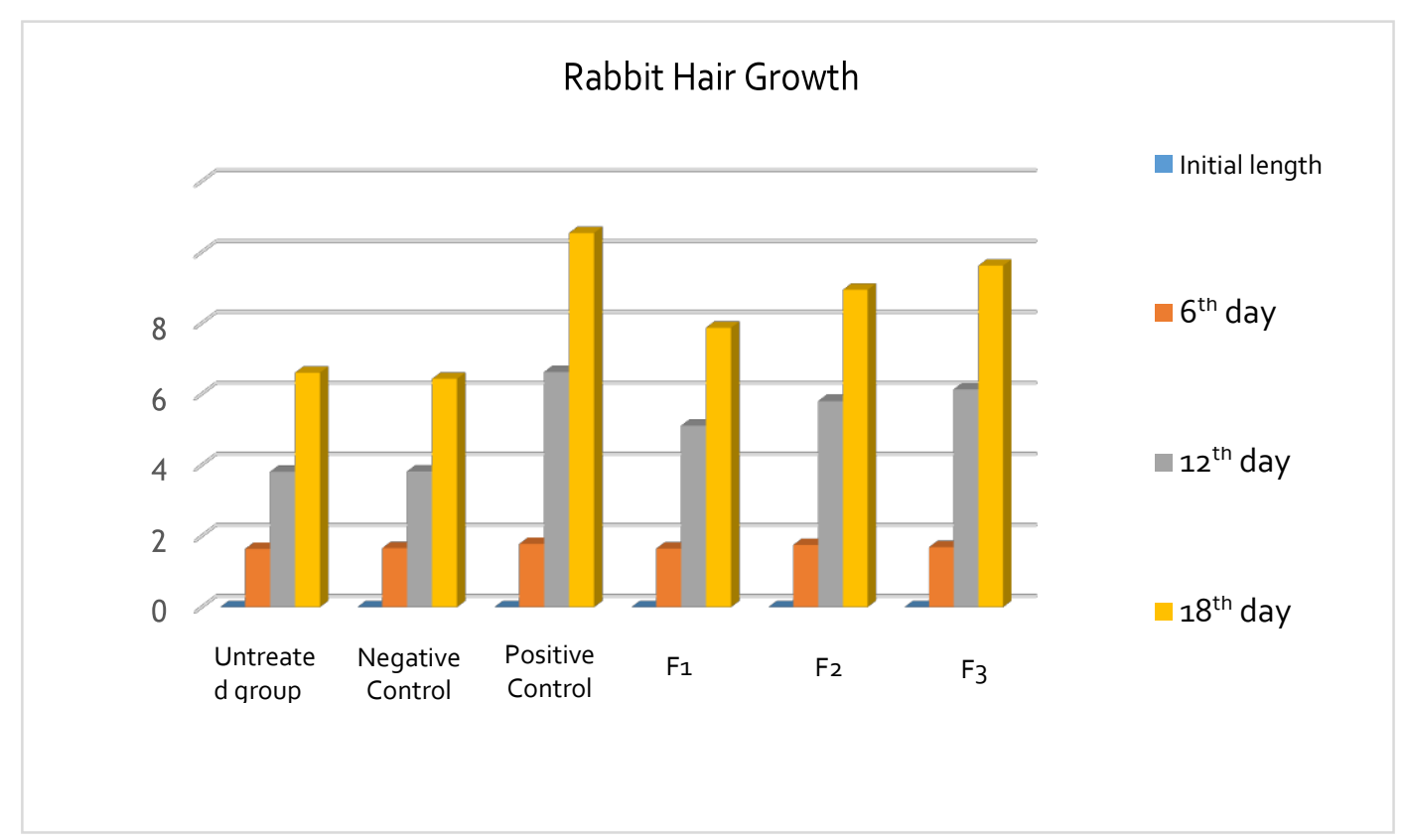

Figure 3. Diagram of Preparation Effectiveness of Black Tea Extract Hair Tonic

Based on the measurement data of the rabbit hair length, it is known that the six treatments given between treatments had very significantly different activities in accelerating hair length growth. For the hair growth effect of each treatment, the addition of black tea extract could increase hair growth activity. Based on the hair growth diagram, each treatment group was negative control, which was applied a base without an active substance, formula $1(1.25 \%)$, formula $2(2.5 \%)$, formula 3 $(5 \%)$, and positive control group (minoxidil), which was compared to the untreated group. Increased hair growth occurred every day; the increase in hair growth was significantly different on the 18th day, and the highest increase was in formula 3, with a $5 \%$ black tea extract concentration.

Based on the follow-up test with the F-test on ANOVA, each treatment showed different results. Formula 1, formula 2, formula 3 , and positive control gave significantly different results. However, only negative and normal controls gave results that were not significantly different.

Moreover, derivatives of flavonoid compounds consist of epigallatocatechin gallate (EGCG), epigallatocatechin (EGC), epicatechin gallate (ECG), epicatechin (EC) and quercetin. In black tea, the polyphenols have a mechanism of action by stimulating and increasing cell proliferation in hair dermal papilla cells, suppressing the production of Tumor Necrosis Factor-alpha (TNF alpha), which triggers baldness ${ }^{14,15}$. Meanwhile, saponins are compounds that can stimulate hair growth, seen from their properties as counterirritants. Saponins can also increase peripheral blood circulation to increase hair growth. In this study, flavonoid and saponin compounds in black tea extract were suspected of playing a role in accelerating hair growth in rabbits, where the more extracts added to hair tonic preparations, the higher the effect in accelerating hair growth. 


\section{CONCLUSION}

Black tea extract formulated as a hair tonic preparation gave physically stable results for all three formulas. The formula of black tea extract hair tonic, which is effective for hair growth, is formula 3, with a $5 \%$ black tea extract concentration.

\section{REFERENCES}

1. Bariqina, E., \& Ideawati, Z., (2011). Perawatan \& Penataan Rambut. Yogyakarta: Adicita Karya Nusa.

2. Horev L. (2007). Environmental and Cosmetic Factors in Hair Loss and Destruction. Curr Probl Dermatol. 35, 103-17.

https://doi.org/10.1159/0000106418

3. Rassman, W. R., \& Bernstein, R. M., Szaniawski, W., \& Halperin, A. (2009). Hair Loss \& Replacement for Dummies. Indianapolis: Wiley Publishing Inc.

4. Tranggono, R. (2007). Buku Panduan Ilmu Pengetahuan Kosmetik. Jakarta: PT.Gramedia Pustaka Utama

5. Riska, N. H., Dolih, G., Rini, H., Resmi, M. (2020). Formulasi dan Evaluasi Sediaan Herbal Hair Tonic Sebagai Perangsang Pertumbuhan Rambut. Majalah Farmasetika, 5 (5), 218-232. https://doi.org/10.24198/mfarmasetik a.v5i5.27555

6. Rejeki, E. S. (2010). Analisis Etanol Dalam Hair Tonic Dan Hair Spray Secara Kromatografi Gas. Surakarta: Universitas Setia Budi

7. Kartodimedjo, S. (2013). Cantik Dengan Herbal Rahasia Puteri Keraton. Yogyakarta: Citra Media Pustaka.

8. Longo, G., Karan, M., Sharma, P. D Rakesh D.D, Vyas S, Vasist. K. (2008). Quantitative Analysis of Green Tea Polyphenosin Indian Cultivars, In Economic Crisis In Tea Industry. Studium Press LIc: Houston USA.
9. Putra, H. T. P. (2013). Formulasi dan Uji Efektivitas Sediaan Emulsi Perangsang Pertumbuhan Rambut Ekstrak Seledri (Apium Graveolens Linn). Skripsi. Universitas Pakuan. Bogor

10. Ditjen POM RI. (1986). Sediaan Galenik. Departemen Kesehatan Republik Indonesia: Jakarta

11. Rahman, L., Marzuki, A., Sukamto \& Musdalifah Azis. (2021). Antibacterial Cream Activity Test of Banyuru Extract Combination (Pterospermum Celebicum Miq) Dan Bee Pollen. Eco. Env. \& Cons. 27 (2), pp. 709-715.

12. Martin, Alfred. (2008). Farmasi Fisika Dasar-Dasar Farmasi Fisika Dalam Ilmu Farmasetik Ed. Ketiga. Jakarta: Uipress.

13. Mu'ani, H., \& Purwati. (2019). Uji Stabilitas Fisik Dan Uji Aktivitas Sediaan Hair Tonic Dari Ekstrak Etanol 96\% Daun Kangkung (Ipomoea Aquatica Forsk.) Pada Rambut Kelinci Jantan (New Zealand White). Indonesia Natural Research Pharmaceutical Journal, 4(2), pp. 23-31 14. Purwantini, I., Munawaroh, R., Darwati N., B.S. (2008). Combination of the And Mangkokan Leaves Extract to Promote Hair Growth, Traditional Medicine Journal 13, p. 43.

15. Amin, J. Simamora, E. L. P., Effionora, A. \& Djajadisastra, J. (2014). Green Tea (Camellia Sinensis L) Ethanolic Extract as Hair Tonic in Nutraceutical; Physical Stability, Hair Growth Activity on Rats, And Safety Test. International Journal of Pharmacy and Pharmaceutical Sciences. 6 (5), pp. 9499. 